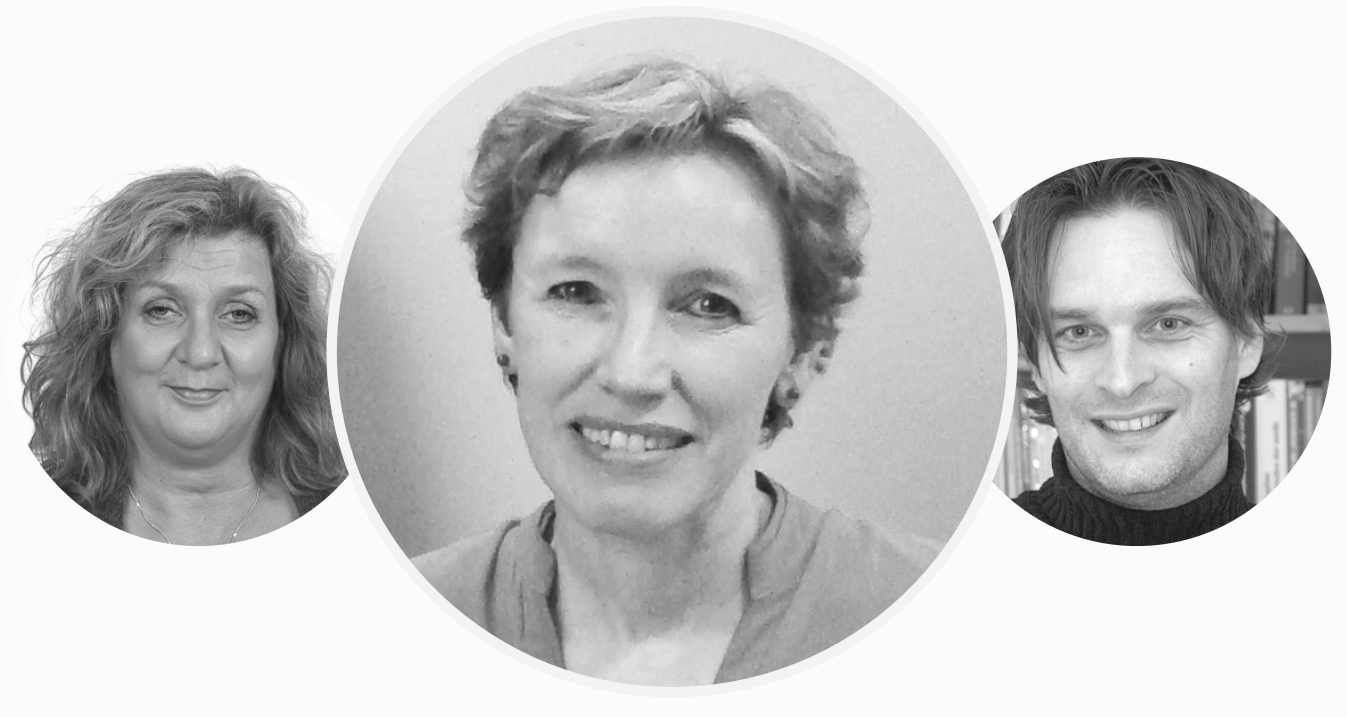

Margo Trappenburg

\section{Langs een omweg werken}

Een van de aardigste zaterdagrubrieken in de Volkskrant heet 180 graden.Wetenschappers en politici vertellen daarin hoe ze radicaal van mening zijn veranderd over een bepaald issue en waarom.VVD-politicus Eric van der Burg vertelde bijvoorbeeld hoe hij van mening veranderde over verzorgingshuizen. Aanvankelijk deelde hij het VVD-standpunt dat verzorgingshuizen te duur waren en dat moderne ouderen beter thuis konden blijven wonen, liefdevol verzorgd door hun sociale netwerk. Eenmaal wethouder in Amsterdam zag hij de nadelen van dit beleid; een verstopte woningmarkt, overal dure trapliften en immobiele ouderen die vereenzaamden zonder contact met leeftijdgenoten. Nu pleit hij voor de terugkeer van verzorgingshuizen.

Aan die rubriek zou ik graag eens meedoen, want ook ik ben 180 graden van mening veranderd en dat komt door sociaal werkers.Vroeger, toen ik onderzoek deed in de gezondheidszorg, was ik sterk aanhanger van het gescheiden-sferen-principe. Artsen horen zich te beperken tot medische problemen. In de jaren vijftig waren er nog wel huisartsen die achter de rug van hun patiënt om gingen bellen met zijn baas, als ze meenden dat de buikpijn werd veroorzaakt door zijn werk, maar dat was tien jaar later al not done. Niet transparant. Onprofessioneel. Een inbreuk op de privacy van de patiënt. Je bent er voor de buikpijn, niet voor de arbeidsomstandigheden.

Van sociaal werkers leerde ik dat het niet altijd zo werkt. De mooiste verhalen over sociaal werk gaan over werken langs een omweg: 'Ik vertelde de cliënt dat we heel hard een klaverjaspartner nodig hadden en zo slaagde ik erin hem het huis uit te krijgen'; 'Deze dementerende bejaarde voelde zich veel te goed voor een dagopvang. Ik vertelde haar dat we daar een vrijwilligster nodig hadden om de ouderen te helpen; dat wou ze wel!' Het beste voorbeeld van langs een omweg werken is de multifunctionele ruimte: een kinderboerderij waar mensen met hun kinderen of kleinkinderen naar toegaan, die tegelijk een sociale werkplaats is of een dagopvang voor medewerkers met een verstandelijke beperking, met als impliciet doel dat beide groepen elkaar in een veilige setting kunnen ontmoeten. Een buurthuis dat verschillende doelgroepen bedient: kinderen die er komen voor muziekles, huiswerkbegeleiding of een knutselclub, een huisarts-ondersteuner die er spreekuur houdt, yogalessen voor vrouwen uit de buurt en een inloopruimte bemand door chronisch psychiatrische patienten. Met als bedoeld bijeffect dat heel verschillende mensen toch af en toe elkaars gezicht zien en even hallo zeggen en soms als gelukkige uitkomst dat de ggz-patiënt aan de slag gaat bij de knutselclub of de huiswerkbegeleiding.

Werken langs een omweg: ik weet nog niet of ik het ook in de gezondheidszorg zou adviseren, maar ik heb bij sociaal werkers gezien hoe het werkt.

\author{
Margo Trappenburg \\ is bestuurskundige \\ aan de Universiteit \\ Utrecht en hoogleraar \\ Grondslagen van het \\ Maatschappelijk Werk \\ aan de Universiteit voor \\ Humanistiek.
}

